\title{
RFLP analysis of a PCR-amplified fragment of the 165 rRNA gene as a tool to identify Enterococcus strains
}

\author{
EMD Scheidegger ${ }^{1}$, SAP Fracalanzza ${ }^{1,2}$, LM Teixeira ${ }^{3}$, P Cardarelli-Leite ${ }^{1,2}{ }^{+}$ \\ 1Programa de Pós Graduação em Vigilância Sanitária ${ }^{2}$ Departamento de Microbiologia, Instituto Nacional de Controle de Qualidade \\ em Saúde-Fiocruz, Av. Brasil 4365, 21045-900 Rio de Janeiro, RJ, Brasil ${ }^{3}$ Instituto de Microbiologia Professor Paulo de Góes, \\ Universidade Federal do Rio de Janeiro, Rio de Janeiro, RJ, Brasil
}

Restriction fragment length polymorphism (RFLP) analysis of a PCR-amplified fragment of the $16 S$ rRNA gene was performed on reference strains belonging to 21 different enterococcal species and on 75 Enterococcus isolates recovered from poultry meat, pasteurised milk and fresh cheese. PCR amplification generated a 275 bp fragment, which was digested with three restriction endonucleases (DdeI, HaeIII, HinfI). The strains were divided into five groups (groups A-E) on the basis of their restriction patterns. Five biochemical tests (arabinose, arginine, manitol, methyl$\beta$-D-glucopyranoside and raffinose) were then performed in addition to RFLP analysis to narrow the identification of enterococcal strains to the species level. PCR-RFLP, in conjunction with the selected biochemical tests, allowed the precise identification of the 21 species of Enterococcus included in the present study. This proposed method is relatively simple and rapid and can be useful as an adjunct tool for accurate identification of Enterococcus.

Key words: 16S rRNA gene PCR-RFLP - Enterococcus identification - food isolates - PCR-based identification phenotypical characterisation

The protection of the food supply requires analysis of the microbiologic quality and safety of commodities that are available for public consumption. While such concerns most frequently address pathogenic micro-organisms that present immediate risks to human health, there is a growing interest in the commensal micro-biota associated with food (Giraffa et al. 1997, Giraffa 2002, Hayes et al. 2003, Mannu et al. 2003). Commensal bacteria contaminate food, water and the environment and they may also be involved in the spreading of antimicrobial resistance to pathogenic or to other commensal microorganisms, which may then infect or colonise humans and animals (van den Bogaard \& Stobbering 2000).

In this context, members of genus Enterococcus deserve major attention. They are ubiquitous bacteria, widely distributed in a variety of habitats. They make up a large proportion of the saprophyte bacteria associated with the gastrointestinal tracts of humans and animals and they are usually found in large numbers in soil, water and food of both vegetable and especially of animal origin, particularly in beef, poultry and swine carcasses (Franz et al. 1999, Giraffa 2002, Domig et al. 2003).

Enterococci are important nosocomial pathogens with a remarkable capacity for resistance to antimicrobial agents. Their ubiquitous nature and resistance to adverse environmental conditions account for their ability to colonise different habitats and underlie their potential

Financial support: FIOTEC, FAPERJ, CNPq, MCT/PRONEX + Corresponding author: paola.cardarelli@incqs.fiocruz.br Received 1 July 2009

Accepted 2 September 2009 to easily spread through the food chain (Giraffa et al. 1997, Giraffa 2002, Fracalanzza et al. 2007).

Classical identification methods for enterococci based on phenotypic traits are often time consuming. Furthermore, subjective interpretative criteria, lack of standardisation and the occurrence of strains with atypical biochemical characteristics have increased the interest in molecular approaches for identification (Marshall et al. 1999).

Bacterial 16S rRNA is a common target for taxonomic purposes, largely due to the mosaic composition of phylogenetically conserved and variable regions within the gene (De Rijk et al. 1992, Gurtler \& Stanisich 1996). Many investigators have targeted the 16S or 23S rRNA gene in order to identify species belonging to a variety of genera, including Campylobacter (Cardarelli-Leite et al. 1996, Iriarte \& Owen 1996, Marshall et al. 1999, Jeng et al. 2001), Salmonella (Shah \& Romick 1997) and Enterococcus (Palepou et al. 1998, Teng et al. 2001, Bersos et al. 2004). PCR-restriction fragment length polymorphism (PCRRFLP) of the groESL sequences of Streptococcus species has also been developed and used for taxonomies (Chen et al. 2008). However, these methods are sometimes narrow in their application or require lengthy and highly complex PCR-RFLP schemes as part of the identification protocol.

To overcome the difficulties mentioned above, we report that a relatively simple PCR-RFLP-based identification method combined with specific biochemical tests can be used to discriminate between many species of Enterococcus isolated from food sources. This approach was shown to be more discriminatory and reliable than identification based on phenotypic tests only.

\section{MATERIALS AND METHODS}

Bacterial strains - A total of 96 Enterococcus strains were studied, including 21 reference strains and 75 selected isolates recovered from foodstuffs. The 
following strains of 21 enterococcal species were used to standardise the PCR-RFLP technique: Enterococcus asini ATCC 700915, Enterococcus avium ATCC 14025, Enterococcus canis LMG 11738, Enterococcus casseliflavus ATCC 25788, Enterococcus columbae ATCC 51263, Enterococcus dispar ATCC 51266, Enterococcus durans ATCC 19432, Enterococcus faecalis ATCC 19433, Enterococcus faecium ATCC 19434, Enterococcus gallinarum ATCC 49573, Enterococcus gilvus ATCC BAA-350, Enterococcus haemoperoxidus ATCC BAA-382, Enterococcus hirae ATCC 8043, Enterococcus malodoratus ATCC 43197, Enterococcus moraviensis ATCC BAA-383, Enterococcus mundtii ATCC 43186, Enterococcus pallens ATCC BAA-351, Enterococcus raffinosus ATCC 49427, Enterococcus ratti ATCC 700914, Enterococcus saccharolyticus ATCC 43076 and Enterococcus sulfureus ATCC 49903. The 75 food isolates were obtained in ongoing studies in our laboratories. They were selected for inclusion in the present study based on their phenotypes. The isolates were recovered from poultry meat (48 isolates), pasteurised milk (6 isolates) and fresh minas cheese (21 isolates) obtained in retail stores in Rio de Janeiro (RJ), Brazil from October 2002-October 2008. Bacteria were isolated from food samples according to the methodology proposed by Andrews and June (1998), with a few modifications. Briefly, poultry or cheese samples $(25 \mathrm{~g})$ were placed in sterile plastic bags containing $225 \mathrm{~mL}$ of buffered peptone (Oxoid Limited, Hampshire, UK) water and homogenised at $230 \mathrm{rpm}$ for $2 \mathrm{~min}$ in a laboratory blender (Stomacher, Seward Limited, London, UK). Pasteurised milk samples (25 $\mathrm{mL}$ ) were homogenised in $225 \mathrm{~mL}$ of buffered peptone water in a sterile flask. Aliquots $(1 \mathrm{~mL})$ of the homogenates were plated on Enterococcosel agar (Becton Dickinson Microbiology Systems, Sparks, MD, USA) plates. Up to five typical colonies suggestive of Enterococcus were randomly selected from each primary isolation culture on Enterococcosel agar for further identification. The isolates were identified on the basis of cellular morphology following Gram stain and the results of the following biochemical tests: catalase production, pyrrolidonyl arylamidase activity, growth in $6.5 \% \mathrm{NaCl}$ broth, hydrolysis of esculin in the presence of bile, pigment production, haemolytic activity, arginine hydrolysis, tolerance to tellurite, utilisation of pyruvate, motility and acid production from L-arabinose, mannitol, methyl- $\beta$-D-glucopyranoside (MGP), D-raffinose, sorbitol, sorbose and sucrose (Facklam \& Collins 1989, Teixeira et al. 2007).

Bacterial DNA extraction - Bacteria were grown on brain heart infusion agar for $24 \mathrm{~h}$ at $37^{\circ} \mathrm{C}$. Bacterial cells from half the plate were harvested with a sterile loop and suspended in $0.3 \mathrm{~mL}$ of lysis buffer from the Puregene Gentra System Genomic isolation kit (Minneapolis, MN, USA). The DNA was extracted as recommended by the manufacturer. DNA concentrations were estimated by the Gene Quant Pro spectrophotometer (Amersham Biosciences, Piscataway, NJ) and up to $100 \mathrm{ng}$ was used for PCR amplification.
Detection of genus-specific genes - In addition to the classical phenotypic characterisation, all isolates were confirmed at the genus level (16S rRNA gene) by a PCR-based assay, as described by Deasy et al. (2000) with slight modifications. E. faecalis SS1273 and E. faecium SS1274 were used as positive control strains for the PCR reaction. The PCR reaction mixture was as recommended by Perkin-Elmer (Norwalk, CT, USA) with the $\mathrm{MgCl}_{2}$ concentration optimised to $2.5 \mathrm{mM}$. The DNA in the reaction mixture $(2 \mu \mathrm{L})$ was denatured at $95^{\circ} \mathrm{C}$ for $4 \mathrm{~min}$. The amplification cycles consisted of denaturation at $95^{\circ} \mathrm{C}$ for $30 \mathrm{~s}$, annealing at $55^{\circ} \mathrm{C}$ for $60 \mathrm{~s}$ and elongation at $72^{\circ} \mathrm{C}$ for $60 \mathrm{~s}$. After 30 amplification cycles, a final elongation step was performed at $72^{\circ} \mathrm{C}$ for $7 \mathrm{~min}$; the samples were maintained at $4^{\circ} \mathrm{C}$ until they were tested. Reactions also contained 240 $\mathrm{nM}$ each primer, $0.2 \mathrm{mM}$ (each) dNTPs and $1.25 \mathrm{U}$ Taq DNA polymerase (Perkin-Elmer).

Detection of species-specific genes - The molecular identification of E. faecalis ( ${ } d l_{E \text { faecalis }}$ gene) and $E$. faecium ( $d d l_{E . f a e c i u m}$ gene) was performed by speciesspecific PCR assays as described by Dutka-Malen et al. (1995) with slight modifications. E. faecalis SS1273 and E. faecium SS1274 were used as positive control strains for the PCR reaction. The PCR reaction mixture was as recommended by Perkin-Elmer with the concentration of magnesium optimised for each primer set $(7 \mathrm{mM}$ for $d d l_{E . f a e c a l i s}$ and $3.5 \mathrm{mM}$ for $\left.d d l_{E . f a e c i u m}\right)$. The DNA in the reaction mixture $(2 \mu \mathrm{L})$ was denatured at $94^{\circ} \mathrm{C}$ for $3 \mathrm{~min}$. The amplification cycles consisted of denaturation at $94^{\circ} \mathrm{C}$ for $60 \mathrm{~s}$, annealing at $52^{\circ} \mathrm{C}$ (for $d d l_{E}$ or $54^{\circ} \mathrm{C}$ (for $d d l_{E \text { faecium }}$ ) for $60 \mathrm{~s}$ and elongation at $72^{\circ} \mathrm{C}$ for $60 \mathrm{~s}$. After 30 amplification cycles, a final elongation step was performed at $72^{\circ} \mathrm{C}$ for $7 \mathrm{~min}$; the samples were maintained at $4^{\circ} \mathrm{C}$ until they were tested. Reactions also contained $240 \mathrm{nM}$ each primer for $d d l_{\text {f }}$ and for $d d l_{\text {Efaecium }}, 0.2 \mathrm{mM}$ (each) dNTPs and $1.25 \mathrm{U} \mathrm{U}$ Taecalis DNA polymerase (Perkin-Elmer).

PCR amplification for PCR-RFLP - The 16S rRNA gene was amplified by PCR with the following primers (in conserved regions of the 16S rRNA gene): forward primer PLO6 (Greisen et al. 1994), 5'-GGTTAAGTCCCGCAACGAGCGC-3'; reverse primer CAMPC5 (Blom et al. 1995), 5'-GGCTGATCTACGATTACTAGAT-3'. Primers were synthesised by Invitrogen (São Paulo, SP, Brazil). PCR amplification was carried out in $100 \mu \mathrm{L}$ volumes containing $2 \mu \mathrm{L}$ of bacterial DNA and $98 \mu \mathrm{L}$ of amplification cocktail, which contained the following components: 15 pmol each primer, $0,2 \mathrm{mM}$ (each) dNTPs, $10 \mu \mathrm{L}$ of GeneAmp PCR buffer (Perkin-Elmer) and 2.5 $\mathrm{U}$ of Taq DNA polymerase (Perkin-Elmer). The PCR amplification was performed in a GeneAmp PCR System 2400 (Applied Biosystems, Foster City, CA, USA). Samples were incubated for $2 \mathrm{~min}$ at $96^{\circ} \mathrm{C}$ to denature the target DNA and went through 30 cycles of $94^{\circ} \mathrm{C}$ for $30 \mathrm{~s}, 50^{\circ} \mathrm{C}$ for $30 \mathrm{~s}$ and $72^{\circ} \mathrm{C}$ for $1 \mathrm{~min}$. The samples were then incubated at $72^{\circ} \mathrm{C}$ for $10 \mathrm{~min}$ for a final extension and were maintained at $4^{\circ} \mathrm{C}$ until they were tested. An amplicon of $275 \mathrm{bp}$ was expected. 
Restriction digest of the amplified DNA - Aliquots of $10 \mu \mathrm{L}$ of each $275 \mathrm{bp}$ amplified product were digested with restriction endonucleases as recommended by the manufacturer. Three restriction enzymes, DdeI, HaeIII and Hinf I (Promega, Madison, WI, USA), were used in separate reactions.

Electrophoresis - Amplified DNA was detected on 1\% agarose gels [1\% agarose (GIBCO-BRL, Gaithersburg, MD, USA) plus $1.5 \%$ NuSieve agarose (3:1) (NuSieve, FMC BioProducts, Rockland, ME, USA)] in 1X Tris-borate-EDTA buffer at $90 \mathrm{~V}$ for $90 \mathrm{~min}$, while the restriction fragments were separated on $4 \%$ NuSieve agarose (3:1) at $90 \mathrm{~V}$ for $210 \mathrm{~min}$. The gels were stained with ethidium bromide and photographed. Photographs of the gels were analysed visually. Fragment sizes were assessed against a 50 bp DNA ladder (GIBCO-BRL, Grand Island, NY, USA) and a 25 bp DNA ladder (GIBCO-BRL).

Nucleotide sequence accession numbers - Reference sequences from GenBank were used to compare the sizes of the observed restriction fragments with the ones expected based on published sequences. The GenBank accession numbers for 16S rRNA gene sequences (including the sequences of the two universal amplification primers) are as follows: Y11621 for E. asini, AJ301825 for E. avium, AY156090 for E. canis, EF199997 for E. casseliflavus, AJ301828 for E. columbae, AJ301829 for E. dispar, EU333895 for E. durans, FJ378704 for $E$. faecalis, FJ378707 for E. faecium, EF025908 for E. gallinarum, EF535229 for E. gilvus, AF286832 for E. haemoperoxidus, FJ378895 for E. hirae, DQ223886 for $E$. malodoratus, AF286831 for E. moraviensis, Y18340 for E. mundtii, DQ411812 for E. pallens, DQ223885 for $E$. raffinosus, DQ411816 for E. saccharolyticus, DQ411815 for E. sulfureus and AF539705 for E. ratti.

\section{RESULTS}

The PCR-RFLP patterns obtained for the 21 reference strains with our three restriction endonucleases approach are summarised in Table I. The strains were divided into five groups (groups A-E) based on their restriction patterns (Fig. 1). Unlike other Enterococcus species, E. faecalis and E. ratti presented unique restriction patterns (patterns A and E, respectively). Each reference strain was submitted to PCR-RFLP analysis 2-4 times; all restriction patterns were reproducible.

When the results obtained by PCR-RFLP were analysed in association with the results of phenotypic testing, the species included in pattern groups B, C and $\mathrm{D}$ could be distinguished by 1-5 phenotypic tests. Fig. 2 shows a scheme for the identification of Enterococcus species based on PCR-RFLP of the 16S rRNA gene using three restriction enzymes (DdeI, HaeIII, Hinf $\mathrm{I})$ and a few biochemical tests selected from the scheme proposed by Teixeira et al. 2007.

The 75 Enterococcus samples isolated from food were identified at the genus level by a PCR-based assay as described. Typical and atypical isolates of $E$. faecalis, E. faecium, E. casseliflavus and E. gallinarum were also decisively identified by species-specific PCR based assays.
The scheme was then applied to characterise 75 selected isolates recovered from foodstuffs. Of these isolates, 64 were identified at the species level based on the results of phenotypic testing (26 had typical results and 38 had atypical results in 1 or 2 tests) and 11 could not be assigned to an enterococcal species on the basis of biochemical testing only (Table II). All the food isolates were identified at the species level by using the scheme combining PCR-RFLP and 1-5 biochemical tests.

A comparative analysis of the $1500 \mathrm{bp} 16 \mathrm{~S}$ rRNA gene of enterococcal species included in the present study (including the sequences of the two universal amplification primers) deposited in the GenBank verified the polymorphism of the $275 \mathrm{bp}$ rDNA amplicons of the reference strains. Restriction maps were calculated from the amplicon regions of the GenBank sequences using NEBCutter 2.0 (Vincze et al. 2003). The predicted restriction fragments from E. faecalis (representing PCRRFLP group A), E. haemoperoxidus (group B), E. avium (group C), E. faecium (group D) and E. ratti (group E) had the same molecular weights observed experimentally (Table III, Fig. 1).

\section{TABLE I}

Groups of PCR-restriction fragment length polymorphism (PCRRFLP) patterns obtained after enzyme restriction of the $16 \mathrm{~S}$ rRNA gene from the type strains of 21 species of Enterococcus

\begin{tabular}{|c|c|c|c|c|}
\hline \multirow[b]{2}{*}{ Reference strain } & \multicolumn{4}{|c|}{$\begin{array}{c}\text { Fragments }^{a} \\
\mathrm{n}\end{array}$} \\
\hline & Group & $D d e \mathrm{I}$ & HaeIII & Hinf $\mathrm{I}$ \\
\hline Enterococcus faecalis & A & 2 & 1 & $3 a^{*}$ \\
\hline Enterococcus haemoperoxidus & $\mathrm{B}$ & 2 & 2 & $3 a$ \\
\hline Enterococcus moraviensis & - & - & - & - \\
\hline Enterococcus avium & $\mathrm{C}$ & 3 & 1 & $3 a$ \\
\hline Enterococcus durans & - & - & - & - \\
\hline Enterococcus gilvus & - & - & - & - \\
\hline Enterococcus hirae & - & - & - & - \\
\hline Enterococcus malodoratus & - & - & - & - \\
\hline Enterococcus mundtii & - & - & - & - \\
\hline Enterococcus pallens & - & - & - & - \\
\hline Enterococcus raffinosus & - & - & - & - \\
\hline Enterococcus asini & $\mathrm{D}$ & 3 & 1 & 2 \\
\hline Enterococcus canis & - & - & - & - \\
\hline Enterococcus casseliflavus & - & - & - & - \\
\hline Enterococcus columbae & - & - & - & - \\
\hline Enterococcus sulfureus & - & - & - & - \\
\hline Enterococcus dispar & - & - & - & - \\
\hline Enterococcus faecium & - & - & - & - \\
\hline Enterococcus gallinarum & - & - & - & - \\
\hline Enterococcus saccharolyticus & - & - & - & - \\
\hline Enterococcus rattii & $\mathrm{E}$ & 3 & 1 & $3 b^{* *}$ \\
\hline
\end{tabular}

$a$ : the numbers shown in the table stand for the numbers of bands observed on the agarose gel after electrophoresis; $3 \mathrm{a}\left({ }^{*}\right)$ and $3 \mathrm{~b}(* *)$ stand for two different three bands patterns. 
TABLE II

Sources and 16S rRNA PCR-restriction fragment length polymorphism (PCR-RFLP) patterns of 75 Enterococcus isolates recovered from food

\begin{tabular}{|c|c|c|c|}
\hline Species $^{a}$ & $\begin{array}{c}\text { Strains } \\
\mathrm{n} \text { (source) }\end{array}$ & $\begin{array}{l}\text { PCR-RFLP } \\
\text { group pattern }\end{array}$ & $\begin{array}{l}\text { Identification by PCR-RFLP } \\
\text { based scheme }\end{array}$ \\
\hline Enterococcus faecalis & 10 (7 poultry, 2 cheese, 1 milk) & A & E. faecalis \\
\hline E. faecalis (atypical) ${ }^{b}$ & 12 (10 cheese, 1 poultry, 1 milk) & & E. faecalis \\
\hline Not identified $^{c}$ & $1($ milk $)$ & & E. faecalis \\
\hline Enterococcus haemoperoxidus (atypical) & 2 (poultry) & $\mathrm{B}$ & E. haemoperoxidus \\
\hline Not identified & 3 (poultry) & & E. haemoperoxidus \\
\hline Enterococcus gilvus & 1 (poultry) & $\mathrm{C}$ & E. gilvus \\
\hline E. gilvus (atypical) & 6 (poultry) & & E. gilvus \\
\hline Enterococcus hirae & 1 (poultry) & & E. hirae \\
\hline E. hirae (atypical) & 2 (poultry) & & E. hirae \\
\hline Not identified & 1 (poultry) & & E. hirae \\
\hline Not identified & 3 (poultry) & & E. malodoratus \\
\hline Not identified & $1($ milk $)$ & & E.pallens \\
\hline Enterococcus casseliflavus & 9 (6 poultry, 2 cheese, 1 milk) & $\mathrm{D}$ & E. casseliflavus \\
\hline E. casseliflavus (atypical) & 4 (poultry) & & E. casseliflavus \\
\hline Enterococcus durans (atypical) & 1 (poultry) & & E. durans \\
\hline Enterococcus faecium & 3 (2 poultry, 1 cheese) & & E. faecium \\
\hline E. faecium (atypical) & 5 (cheese) & & E. faecium \\
\hline Enterococcus gallinarum & 2 (poultry) & & E. gallinarum \\
\hline E. gallinarum (atypical) & 3 (1 poultry, 1 milk, 1 cheese) & & E. gallinarum \\
\hline Enterococcus sulfureus (atypical) & 3 (poultry) & & E. sulfureus \\
\hline Not identified & 2 (poultry) & & E. sulfureus \\
\hline
\end{tabular}

$a$ : identification based on the results of biochemical tests only; $b$ : atypical, results of one or two biochemical tests did not match with those in the scheme proposed by Teixeira et al. 2007; $c$ : isolates that had more than three atypical biochemical characteristics.

\section{DISCUSSION}

Enterococci are frequently found in foodstuffs, mainly raw products of animal origin (meat and milk) and their presence is an indicator of faecal contamination in sources associated with low hygiene conditions (Mannu et al. 2003).

Data on antibiotic resistance of enterococci associated with foodstuffs provide strong epidemiological evidence of a link between the use of antibiotics in human medicine and animal husbandry and the emergence, spreading and persistence of resistant strains in animal products (van den Bogaard \& Stobbering 2000).

Multi-resistant enterococcal populations are commonly isolated from humans, aquatic environments and sewage. These microbes can be introduced into the human intestinal micro-flora by food consumption. The increasing occurrence of multi-resistant enterococcal isolates and isolates with the propensity to acquire new resistance traits is a major concern for the therapy and control of enterococcal infections (Murray 1998, Teixeira et al. 2007).

In a previous study (Fracalanzza et al. 2007), we reported the occurrence of multiple species as well as antimicrobial resistance profiles among enterococcal isolates from commercial foodstuffs of animal origin (represented by poultry and pasteurised milk) in RJ. A variety of species was identified in 167 isolates obtained from poultry and 127 isolates from pasteurised milk, including E. faecalis (62.6\%), E. casseliflavus (17.3\%), E. durans $(6.5 \%)$, E. gallinarum (3\%), E. gilvus $(2.4 \%)$, E. faecium (2\%), E. hirae (1.4\%) and E. sulfureus $(1 \%)$. Eleven $(3.8 \%)$ of the isolates remained non-identified. Multi-resistance was observed in isolates identified as E. faecalis, E. casseliflavus, E. faecium, E. gallinarum, $E$. durans and E. gilvus. The major risk related to the resistance traits is that they are for the most part transferable to the enterococci and more virulent pathogens as well some of these strains were used to evaluate the PCR-RFLP method in the present study.

In this study, five groups (A-E) with distinct restriction patterns were obtained after PCR-RFLP analysis of 275 bp 16S rDNA amplicons digested with DdeI, HaeIII and Hinf $\mathrm{I}$. The reference Enterococcus strains could be easily differentiated on the basis of restriction patterns produced by these three restriction enzymes in association with the results of selected biochemical tests.

We validated our identification scheme by testing 75 isolates of Enterococcus recovered from foodstuffs. These isolates presented different levels of difficulty of precise identification by biochemical testing only. All 75 food isolates fit into 1-5 PCR-FRLP groups. After the PCR-RFLP 

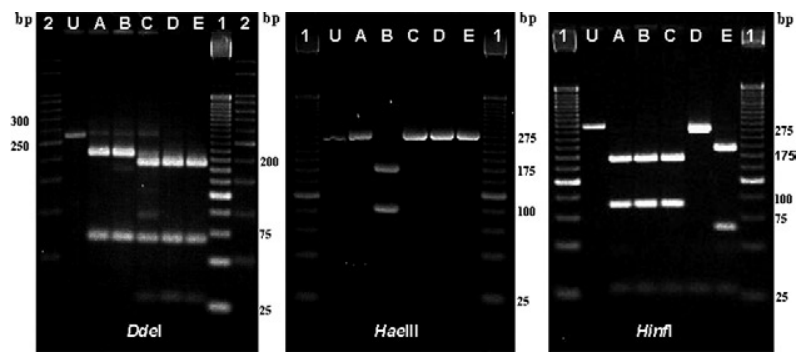

Fig. 1: restriction patterns of a 16S rRNA gene 275-bp fragment amplified by PCR and digested with DdeI, HaeIII and HinfI representing the five different PCR-restriction fragment length polymorphism groups (A-E) that include 21 different species of Enterococcus. Lanes A: Enterococcus faecalis ATCC 19433 representing group A; B: Enterococcus haemoperoxidus ATCC BAA-382 representing group B; C: Enterococcus avium ATCC 14025 representing group C; D: Enterococcus faecium ATCC 19434 representing group D; E: Enterococcus ratti ATCC 700914 representing group E; U: uncut fragment of 275-bp; 1: 25-bp DNA Ladder; 2: 50-bp DNA Ladder.

\section{TABLE III}

Enterococcus $16 \mathrm{~S}$ rRNA gene restriction fragment patterns obtained by using the NEBCutter 2.0 program

\begin{tabular}{lccc}
\hline & \multicolumn{3}{c}{ Restriction patterna according to the enzyme } \\
\cline { 2 - 4 } Pattern group & DdeI & HaeIII & Hinf $\mathrm{I}$ \\
\hline A & $208 / 67$ & 275 & $165 / 85 / 25$ \\
B & $208 / 67$ & $175 / 100$ & $165 / 85 / 25$ \\
C & $184 / 67 / 24$ & 275 & $165 / 85 / 25$ \\
D & $184 / 67 / 24$ & 275 & $250 / 25$ \\
E & $184 / 67 / 24$ & 275 & $190 / 60 / 25$ \\
\hline
\end{tabular}

pattern groups: A: Enterococcus faecalis ATCC 19433 (representing the group A); B: Enterococcus haemoperoxidus ATCC BAA-382 (group B); C: Enterococcus avium ATCC 14025 (group C); D: Enterococcus faecium ATCC 19434 (group D); E: Enterococcus ratti ATCC 700914 (group E). a: size in base pairs.

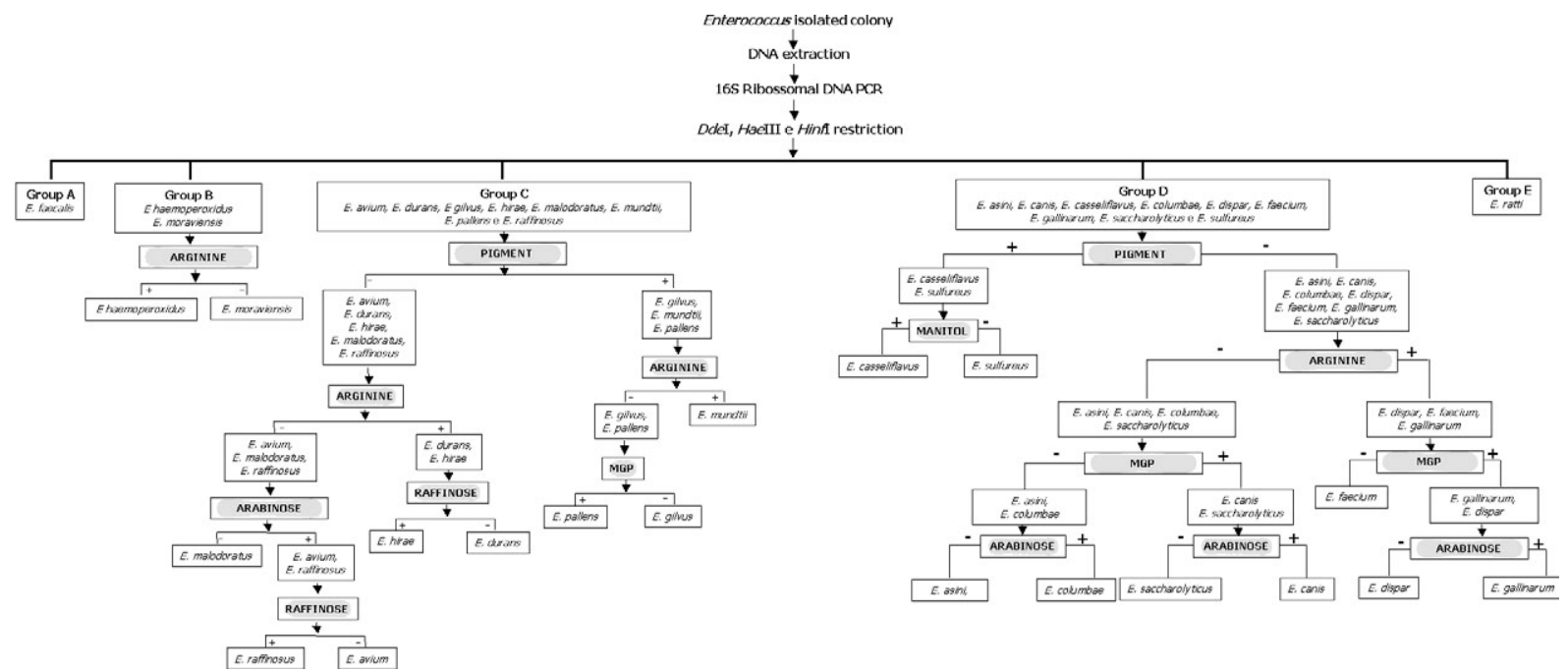

Fig. 2: scheme for rapid identification of the species of Enterococcus by PCR-based RFLP in conjunction with a few biochemical tests.

technique was combined with selected biochemical tests, all isolates could be identified at the species level.

Thirty-seven of the food isolates exhibited atypical phenotypic traits. Among them, eleven E. faecalis and two E. haemoperoxidus strains presented atypical results in the MGP test. Five E. faecium, three E. gallinarum, three E. sulfureus, two E. hirae and one E. gilvus strains presented atypical results in the potassium tellurite test. Three E. casseliflavus strains presented atypical results in the arginine test; two E. gilvus and one E. casseliflavus presented atypical results in the pyruvate and sorbose tests, respectively. One E. faecalis and three $E$. gilvus presented atypical results in the raffinose test. Some of these strains presented atypical results for two physiological tests simultaneously, illustrating the phenotypic diversity of enterococci isolated from foods and the difficulty of identifying these micro-organisms through phenotypic tests alone.
In conclusion, PCR-RFLP combined with a few selected biochemical tests was shown to be a relatively simple, rapid and reliable technique to identify species of Enterococcus even when isolates presented atypical or uncommon phenotypic characteristics. The DNA-based assay developed in this study provides an alternative to current methods for the identification of enterococcal isolates in public health laboratories.

\section{ACKNOWLEDGEMENTS}

To the Support Section and to Dr. Célia Romão, Head of the Microbiology Department of INCQS, for their valorous technical assistance.

\section{REFERENCES}

Andrews WH, June GA 1998. Food sampling and preparation of homogenates. In RL Merker (ed.), Food and drug administration bacteriological analytical manual, 8th ed., AOAC International, Gaithersburg, p. 1-9. 
Bersos Z, Maniati M, Kontos F, Petinaki E, Maniatis AN 2004. First report of a linezolid-resistant vancomycin-resistant Enterococcus faecium strain in Greece. J Antimicrob Chemother 53: 685-686.

Blom K, Patton CM, Nicholson MA, Swaminathan B 1995. Identification of Campylobacter fetus by PCR-DNA probe method. J Clin Microbiol 33: 1360-1362.

Cardarelli-Leite P, Blom K, Patton CM, Nicholson MA, Steigerwalt AG, Hunter SB, Brener DJ, Barrett TJ, Swaminathan B 1996. Rapid identification of Campylobacter species by restriction fragment length polymorphism analysis of a PCR-amplified fragment of the gene coding for 16S rRNA. J Clin Microbiol 34: 62-67.

Chen H-J, Tsai J-C, Chang T-C, Hung W-C, Tseng S-P, Hsueh P-R, Teng L-J 2008. PCR-RFLP assay for species and subspecies differentiation of the Streptococcus bovis group based on groESL sequences. J Med Microbiol 57: 432-438.

De Rijk P, Neefs JM, Van de Peer Y, De Wachter R 1992. Compilation of small ribosomal subunit RNA sequences. Nucleic Acids Res 20: $2075-2089$.

Deasy BM, Rea MC, Fitzgerald GF, Cogan TM, Beresford TP 2000. A rapid PCR based method to distinguish between Lactococcus and Enterococcus. Syst Appl Microbiol 23: 510-522.

Domig KJ, Mayer HK, Kneifel W 2003. Methods used for the isolation, enumeration, characterisation and identification of Enterococcus spp. 1. Media for isolation and enumeration. Int $J$ Food Microbiol 88: 147-164.

Dutka-Malen S, Evers S, Courvalin P 1995. Detection of glycopeptide resistance genotypes and identification to the species level of clinically relevant Enterococci by PCR. J Clin Microbiol 33: 24-27.

Facklam RR, Collins MD 1989. Identification of Enterococcus species isolated from human infections by a conventional test scheme. J Clin Microbiol 27: 731-734.

Fracalanzza SAP, Scheidegger EMD, Santos PF, Cardarelli-Leite P, Teixeira LM 2007. Antimicrobial resistance profiles of enterococci isolated from poultry meat and pasteurized milk in Rio de Janeiro, Brazil. Mem Inst Oswaldo Cruz 102: 853-859.

Franz CMAP, Holzapfel WH, Stiles ME 1999. Enterococci at the crossroads of safety? Int J Food Microbiol 47: 1-24.

Giraffa G 2002. Enterococci from foods. FEMS Microbiol Rev 26: $163-171$.

Giraffa G, Carminati D, Neviani E 1997. Enterococci isolated from dairy products: a review of risks and potential technological use. J Food Prot 60: 732-738.

Greisen K, Loeffelholz M, Purohit A, Leong D 1994. PCR primers and probes for the 16S rRNA gene of most species of pathogenic bacteria, including bacteria found in cerebrospinal fluid. $J$ Clin Microbiol 32: 335-351.
Gurtler V, Stanisich VA 1996. New approaches to typing and identification of bacteria using the $16 \mathrm{~S}-23 \mathrm{~S}$ rDNA spacer region. Microbiology 142: 3-16.

Hayes JR, Enghish LL, Carter PJ, Proescholt T, Lee KY, Wagner DD, White DG 2003. Prevalence and antimicrobial resistance of Enterococcus species isolated from retail meats. Appl Environ Microbiol 69: 7153-7160.

Iriarte P, Owen RJ 1996. PCR-RFLP analysis of the large subunit (23S) ribosomal RNA genes of Campylobacter jejuni. Lett Appl Microbiol 23: 163-166.

Jeng RS, Svircev AM, Myers AL, Beliaeva L, Hunter DM, Hubbes M 2001. The use of $16 \mathrm{~S}$ and $16 \mathrm{~S}-23 \mathrm{~S}$ rDNA to easily detect and differentiate common Gram-negative orchard epiphytes. $J$ Microbiol Methods 44: 69-77.

Mannu L, Paba A, Daga E, Comunian R, Zannetti S, Duprè I, Sacchi LA 2003. Comparison of the incidence of virulence determinants and antibiotic resistance between Enterococcus faecium of animal and clinical origin. Int J Food Microbiol 88: 291-304.

Marshall SM, Melito PL, Woodward DL, Johnson WM, Rodgers FG, Mulvey MR 1999. Rapid identification of Campylobacter, Arcobacter and Helicobacter isolates by PCR-restriction fragment length polymorphism analysis of the $16 \mathrm{~S}$ rRNA gene. $J$ Clin Microbiol 37: 4158-4160.

Murray BE 1998. Diversity among multidrug-resistant enterococci. Emerg Infect Dis 4: 37-47.

Palepou MFI, Adebiyi AMA, Tremlett CH, Jensen LB, Woodford N 1998. Molecular analysis of diverse elements mediating VanA glycopeptide resistance in enterococci. $J$ Antimicrob Chemother 42: 605-612.

Shah SA, Romick TL 1997. Subspecies differentiation of Salmonella by PCR-RFLP of the ribosomal operon using universal primers. Lett Appl Microbiol 25: 54-57.

Teixeira LM, Carvalho MGS, Facklam RR 2007. Enterococcus. In PR Murray, EJ Baron, JH Jorgensen, ML Landry, MA Pfaller (eds.), Manual of clinical microbiology, 9th ed., American Society for Microbiology, Washington DC, p. 430-442.

Teng L-J, Hsueh P-R, Wang Y-H, Lin H-M, Luh K-T, Ho S-W 2001. Determination of Enterococcus faecalis groESL full-length sequence and application for species identification. J Clin Microbiol 39: 3326-3331.

van den Bogaard AE, Stobbering EE 2000. Epidemiology of resistance to antibiotic. Links between animals and humans. Int $J$ Antimicrob Agents 14: 327-335.

Vincze T, Posfai J, Roberts RJ 2003. NEBcutter: a program to cleave DNA with restriction enzymes. Nucleic Acids Res 31: 3688-3691. 